\title{
High-resolution radar on Ice Stream B2, Antarctica: measurements of electromagnetic wave speed in firn and strain history from buried crevasses
}

\author{
'T. S. Glarke aNd C. R. Bentley \\ Geophysical and Polar Research Center, University of Wisconsin-Madison, Madison, WI 53706, U.S.A.
}

\begin{abstract}
ABSTR ACT. Two types of experiments were performed near Upstream B Camp on Ice Stream B2 using a high-resolution ground-penetrating radar system. In the first type of experiment, tracking a metal drill tip through the upper $85 \mathrm{~m}$ of the ice column indicated an approximatcly lincar decrease of wave speed with depth down to $50 \mathrm{~m}$,

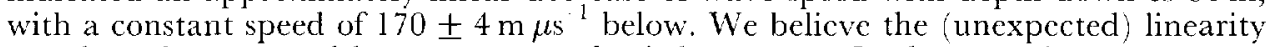
may have been caused by one or more buried crevasses. In the second experiment, a survey of a $250 \mathrm{~km}^{2}$ grid showed a population of buried crevasses at about $30 \mathrm{~m}$ depth that have an estimated burial age of $210 \pm 25$ years, which is taken to indicate that this ice has been exhibiting streaming behavior for at least that length of time. One $3 \mathrm{~km}$ segment along the edge of the survey area nearest the center of the stream showed virtually flat, undisrupted stratigraphy down to the maximum depth of our measurements. The fact that this ice was accelerated from near-zero speed to its present $440 \mathrm{ma}^{-1}$ without cracking or folding suggests that this ice may have been incorporated into the ice stream as a solid block.
\end{abstract}

\section{INTRODUCTION}

The ice streams that drain the West Antarctic ice sheet along the Siple Coast (Fig. 1) have been the focus of

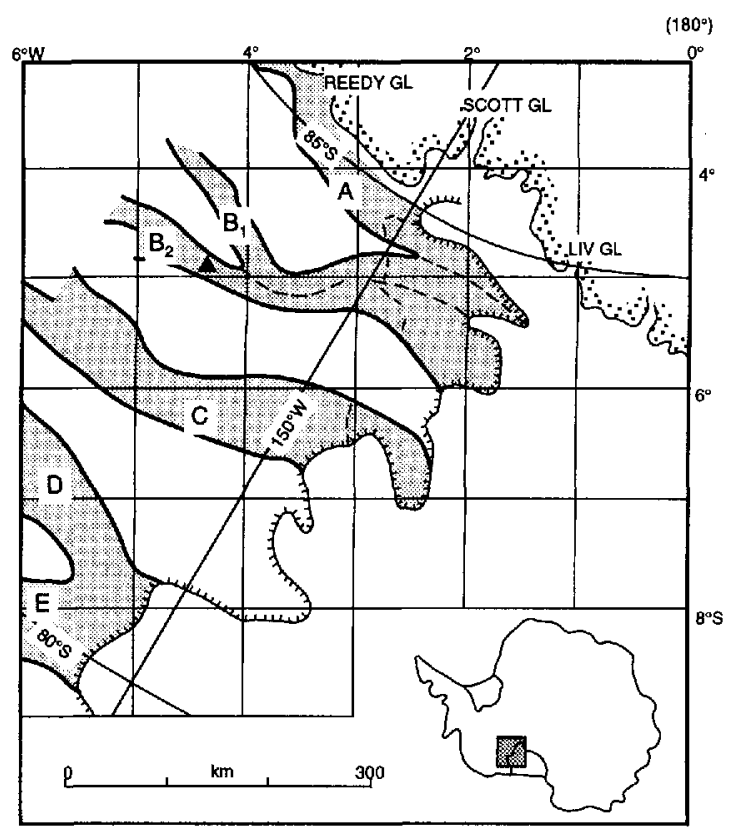

Fig. 1. Map of the ice streams (shaded) draining the West Antarctic ice sheet into the Ross Ice Shelf. The solid triangle on Ice Stream $B 2$ denotes the location of the experiments. The coordinate grid is derived by a simple transformation from polar geographic to rectangular coordinates (From Shabtaie and Bentley, 1987.) numerous glaciologic and geophysical investigations in recent ycars (Alley and Whillans, 1991). A principal purpose for these studies has been to learn more about iccstream dynamics. In this paper, we investigate buried crevasses and associated strain features in the upper $85 \mathrm{~m}$ of a $250 \mathrm{~km}^{2}$ area of Ice Stream B. The data were collected during the 1991-92 field season using a highresolution low-power impulse-type digitally recording ground-penetrating radar system.

The analysis consists of two parts. First, by tracking a target, we determine the variation in radar wave speed versus depth in the upper $85 \mathrm{~m}$ of the ice stream. Secondly, the shapes of diffraction hyperbolae recorded from buried linear features (crevasses, sharp folds or faults) are used to determine the depths and orientations of the buried features. The technique yields orientations from a single crossing and therefore allows cffective mapping using survey-line separations of $1 \mathrm{~km}$ or more.

\section{FIELD METHODS AND DATA ANALYSIS}

\section{Instrumentation}

The radar system comprised a GSSI Model SIR8 transmittcr-receiver coupled to a single $80 \mathrm{MHz}$ broadband transmit receive antenna with a $30 \mathrm{~m}$ cable. Navigation was provided by a combination of a bicyclewheel odometer, a motion detector (used for sensing passage past grid poles accurately positioned by investigators at The Ohio State University (Hulbe and Whillans, 1994)) and an event-marking button. The 


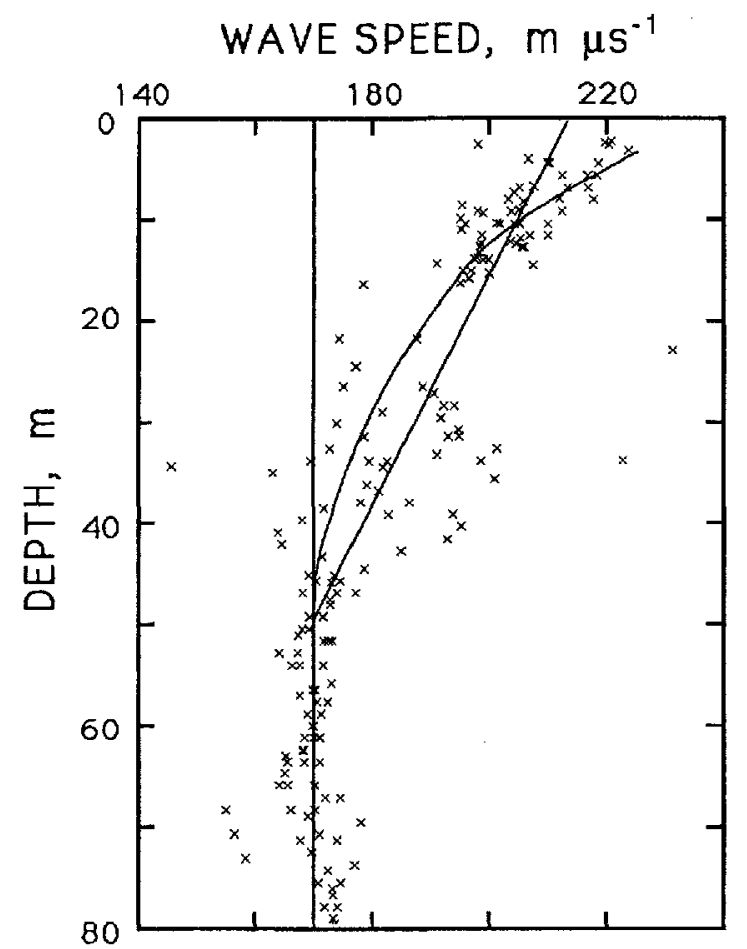

$\mathbf{a}$

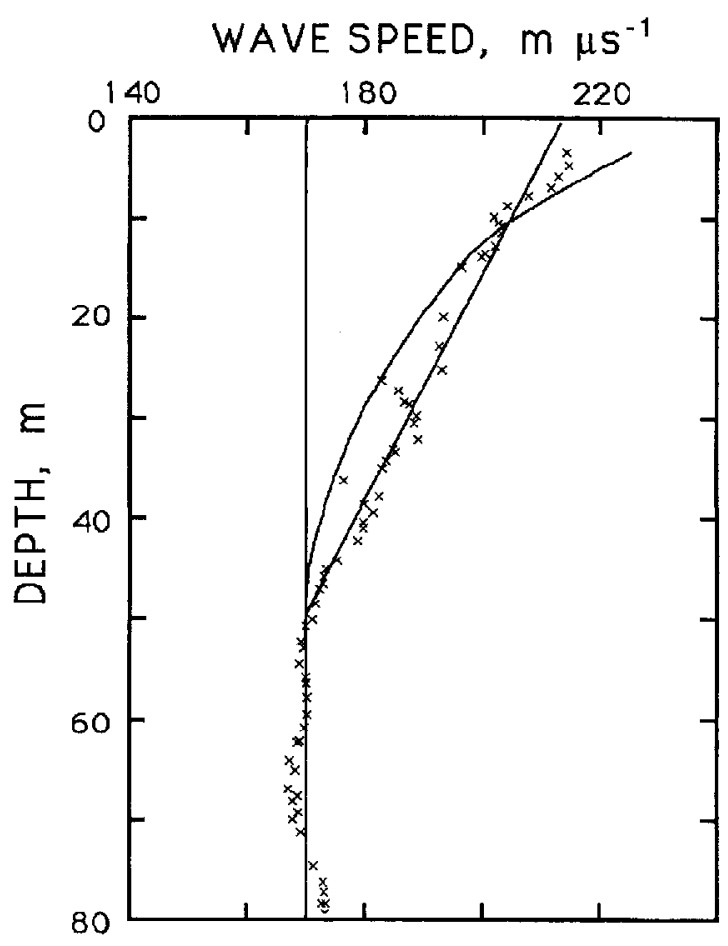

b

Fig. 2. Plots of wave speed versus depth at $U p B$. In each, the vertical line is at $170 \mathrm{~m} \mu \mathrm{s}^{-1}$, the speed below $50 \mathrm{~m}$. The sloping line is a least-squares regression-line fil to the dala, and the curved line shows the wave speed expected from the known variation of density with depth. (a.) Individual measurements. (b.) $5 \mathrm{~m}$ running means.

data were logged directly from the GSSI receiver and navigation systems using a digital data-logging system designed and built at the University of Wisconsin. T'he sampling rate was $969 \pm 12 \mathrm{MHz} \quad(1.032 \pm 0.013 \mathrm{~ns}$ sample ${ }^{-1}$. The data logger was controlled by an IBM lap-top computer and the entire system was powercd from a $12 \mathrm{~V}$ automobile battcry. The relatively light weight and portability of the system allowed it to be mounted on a single Nansen sled; the antenna was towed on another Nansen sled $30 \mathrm{~m}$ behind. The sled train was towed by a Skidoo Alpine snowmobile. Where surface crevasses posed a danger, a sccond Skidoo was added $20 \mathrm{~m}$ behind the antenna sled for salety purposes. The snowmobile sled-sled-snowmobilc arrangement was roped together; personncl were tied together on a separate rope system.

\section{Radar-wave speed in firn}

Investigators from the California Institute of Technology (Caltcch) drilled several holes into and through the ice at Upstream B Camp (Fig. 1) during the 1992-92 field season (e.g. Engelhardt and others, 1990). We used the radar sytem to record echoes from the descending (or ascending) metallic drill tip; from the echo times, the electromagnetic wave specd in the firn was calculated.

Two types of tips were used by Caltech, one $4.2 \mathrm{~m}$ long and one $1.6 \mathrm{~m}$ long. Each hung on the end of a radartransparent nylon-reinforced hose. Our antenna was placed about $7 \mathrm{~m}$ from the top of the borehole. The data-acquisition rate varied between one and four traces per second, while drilling progressed at about $100 \mathrm{~m} \mathrm{~h}^{-1}$. The stem was tracked 12 times going up or down three different holes all within $100 \mathrm{~m}$ of each other. The depth of the stem was determined by calibrated meter wheels. The radar record was marked every 1 or $2 \mathrm{~m}$ in depth by a brief electronic pulse.

Vclocity (v) vcrsus depth $(z)$ was calculated every 1 or $2 \mathrm{~m}$ from pulse travel-lime differences over $3-5 \mathrm{~m}$ depth intervals. A correction was made for the phase reversal from the conducting drill tip. Ray paths were assumed to be straight, an assumption that causes an error in wave speed of less than $1 \%$ at all depths.

Water introduced into the firn by Caltech's hot-water drilling technique apparently had little effect on the measured wave specds. As drilling progressed, large increases in echo strength were observed at specific stratigraphic levels. These changes were interpreted to mean that water was pooling at these particular levels. As long as the water content and thickness of the layer(s) did not change appreciably over the $1-3 \mathrm{~min}$ it took to penetrate (or withdraw through) $3-5 \mathrm{~m}$ of firn, and as long as that 3-5 $\mathrm{m}$ of firn did not include one of these wet layers, the effect of the water was removed by the traveltime differencing.

The speeds are shown in raw form (Fig. 2a) and after a $5 \mathrm{~m}$ running mean has been applied (Fig. 2b). Also shown are least-squares regression lines of the form $v(z)=a+b z$ fitted to the unsmoothed $0-50 \mathrm{~m}$ section. For the raw data (Fig. 2a), $a=213 \pm 10 \mathrm{~m} \mu \mathrm{s}^{-1}$, $b=-0.87 \pm 0.06 \mu \mathrm{s}^{-1}$ and the square of the correlation cocfficient is 0.63 . For the smoothed data (Fig. 2b), the correlation coefficient is $0.96 ; a$ and $b$ are almost unchanged. Below $50 \mathrm{~m}$, the wave speed is constant at $170 \pm 4{\mathrm{~m} \mu \mathrm{s}^{-} \text {. }}^{\text {. }}$

The apparent linear variation with depth is unex- 
pected. 'The density-depth $(\rho(z))$ data presented by Alley and Bentley (1988) show the expected decrease in $\mathrm{d} \rho / \mathrm{d} z$ with depth downward to $50 \mathrm{~m}$, where a solid-ice density of $0.90 \mathrm{Mg} \mathrm{m}^{-3}$ is reached; since $v$ varies lincarly with $\rho$ (Bogorodsky and others, 1985), $v(z)$ should show a similar form. We have plotted the expected $v(z)$, calculated from $\rho(z)$ using the linear relation of Robin and others (1969), in Figure 2. Bctween 0 and $20 \mathrm{~m}$, the measured and calculated wave speeds agree reasonably well, but between 25 and $50 \mathrm{~m}$ our measured velocitics are consistently higher. (A further indication that water had little effect on the measurements.) Closely space gridded traverse lines in the vicinity of the drillholes showed buried crevasses very near two of the three drill locations. In both cases, the crevasse tops were located at about $25 \mathrm{~m}$ depth. We believe that propagation through crevasses is the likely cause of the unusually large wave speeds between 25 and $50 \mathrm{~m}$. Wc note, however, that the data presented here cannot really differentiate between the two curves: the linear $v(z)$ and the expected $v(z)$ fall within 100 and $90 \%$, respectively, of the standard deviations of the $5 \mathrm{~m}$ running means (not shown). For simplicity, we have used the linear relation for determining diffractor depths. The crrors associated with the difference betwecn the two curves are everywhere less than $1 \mathrm{~m}$ in depth and 10 years in age.

\section{Shapes of theoretical diffraction hyperbolae}

Many macroscopic strain features found on glaciers and ice shects are linear in form. It is well known that, if the features are sharp enough, they appcar as diffraction hyperbolae on radar records. Discontinuities associated with crevasses and faults obviously can causc diffraction hy perbolae; so can folding, if it is sharp compared to the curvature of the incident wave front.

We derive a relation between hyperbola shape and crossing angle, assuming the diffractor is a straight line at a constant depth. From the geometry (Fig. 3), $s^{2}=x^{2}+d^{2}$, where $s, x$ and $d$ arc slant, horizontal and rertical distances, respectively, from the antenna to the diffractor Jezek and others, 1979). Also, $s=t^{\prime \prime} \bar{v}, x=$ $\ell \sin \theta$ and $d=t^{\prime} \bar{v}$, where $t^{\prime \prime}$ is the one-way travel time along $s, \bar{v}$ is the average wave speed to depth $d, \ell$ is the distance along the traverse line from the anterna to the crossing point, $\theta$ is the crossing angle and $t^{\prime}$ is the one-way travel time along $d$. For $v=a+b z$, we find by integration $\bar{v}$ as a function of $t^{\prime}: \bar{v}=\left(a / b l^{\prime}\right)\left(\mathrm{e}^{b t^{\prime}}-1\right)$. Then

$$
t^{\prime \prime}=t^{\prime}\left[\left(\frac{\ell b \sin \theta}{a\left(\mathrm{e}^{b t^{\prime}}-1\right)}\right)^{2}+1\right]^{\frac{1}{2}}
$$

From Equation (1), $\sin ^{2} \theta$ can be calculated from the shape of the hyperbola; the $\operatorname{sign}$ of $\theta$ is not determined. Also, the ray path, $s$, is assumed to be straight. This introduces an error of less than $1 \%$ for incident angles of less than $45^{\circ}$, which constitute the majority of incident angles for any given hyperbola.

Several hyperbolae calculated from Equation (1) for different values of $\theta$ are shown in Figure 4 . Calculated and measured hyperbolac from several crevasses that had known oricntations (e.g. Fig. 5) agree within $5^{\circ}$ or $10^{\circ}$, which is good considering that crevasses are not perfectly linear features.

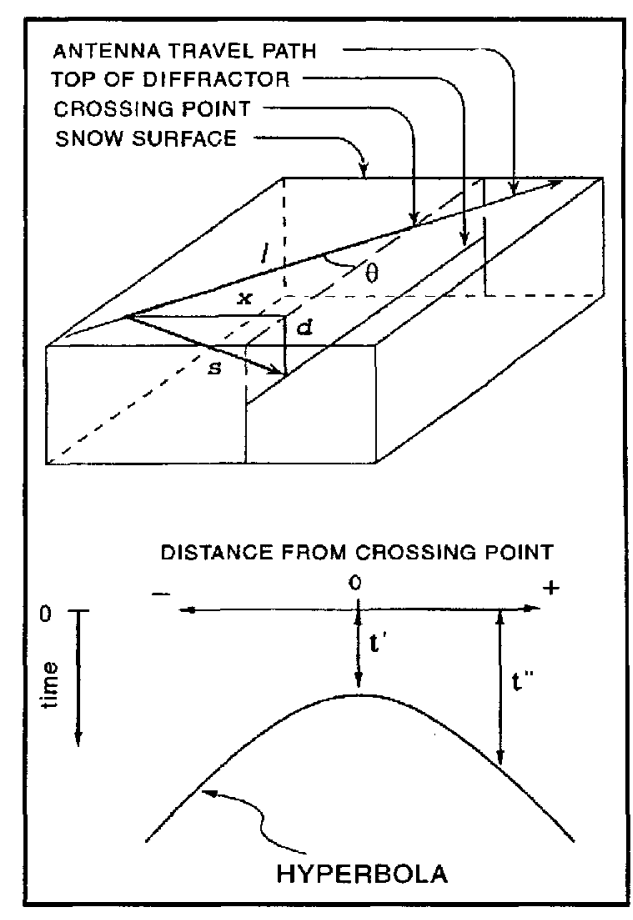

Fig. 3. Sketches showing the assumed geometry, the parameters used in the determination of crevasse orientation and how they relate to an observed hyperbola.

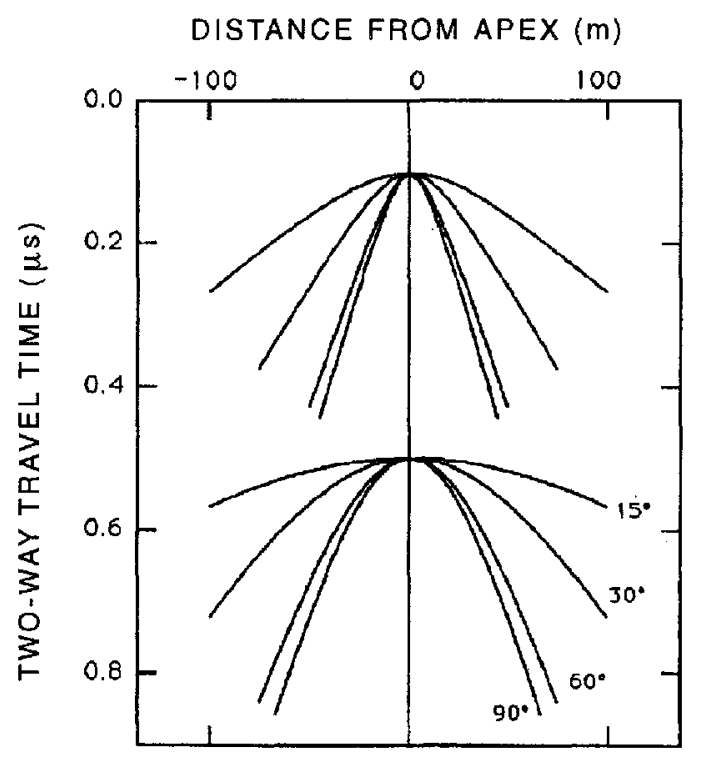

Fig. 4. Theoretical hyperbolae for linear diffractors at depths of $10 \mathrm{~m}$ (upper set) and $48 \mathrm{~m}$ (lower sel) crossed at angles of $15^{\circ}, 30^{\circ}, 60^{\circ}$ and $90^{\circ}$.

\section{Description of buried features}

A number of different types of features produce hyperbolae and it is important to understand these differences if the hyperbolae are to be interpreted accurately. One type of near-surface crevasse produced what can be best described as single-sided hyperbolac (Fig. 6). While the surface cxpression of these crevasses was essentially linear, their edges were very irregular, and attempts to lower wcights into them for measurement of depth were invariably thwarted by multiple snow bridges. Each side of these crevasses is charactcrized on the radargram by a 


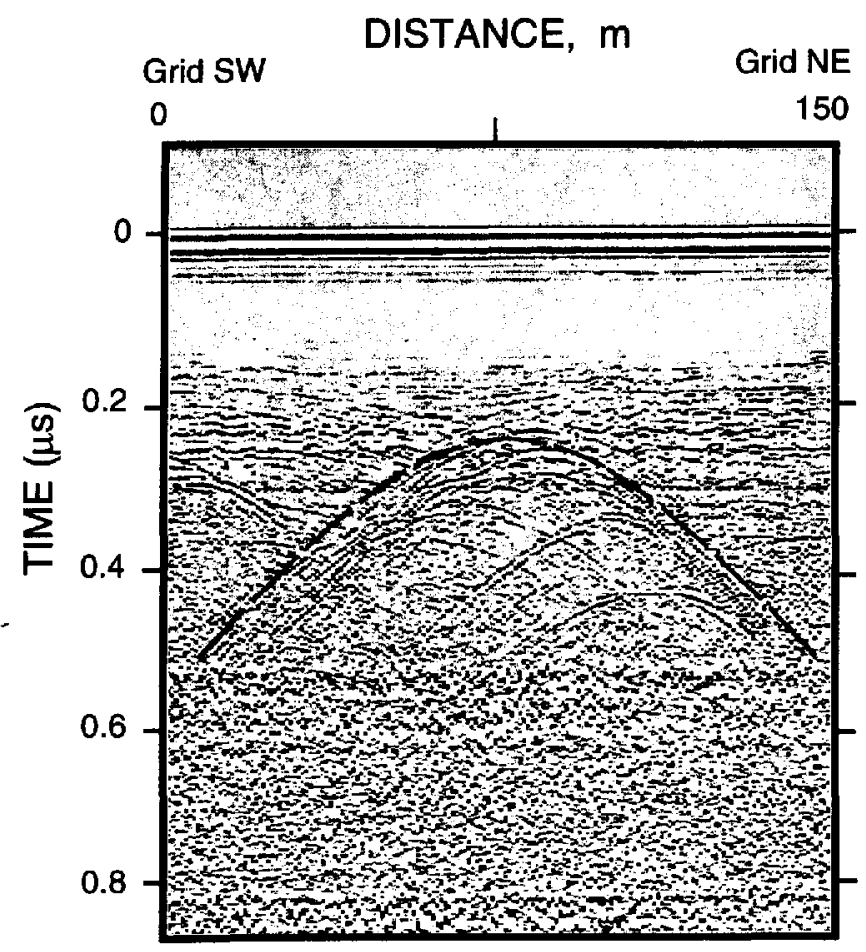

Fig. 5. A calculated hyperbola (dashed line) superimposed on an observed hyperbola. The crossing angle is $45^{\circ}$.

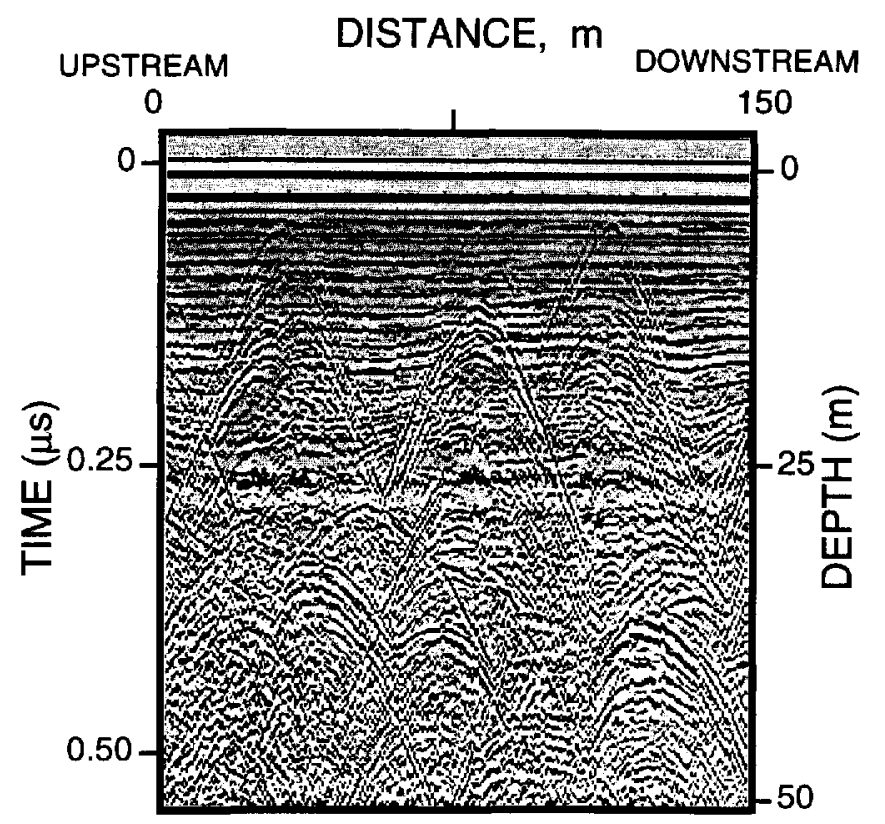

Fig. 6. Radargram we interpret as showing active crevasses with mulliple snow bridges. Stacks of one-sided hyperbolae are particularly well shown in the features around $30 \mathrm{~m}$ from each end of the profile.

scparate set of single-armed hypcrbolac with apices stacked from the surface to a depth of many meters. We interpret this as diffractions from a rough-walled crcvassc, perhaps caused by simultaneous growth and burial.

Another type of signature was observed from freshly opencd, straight-edged, smooth-walled crevasses with burial depths of less than $1 \mathrm{~m}$ (Fig. 7). These show a single strong diffraction hyperbola at depth but almost no

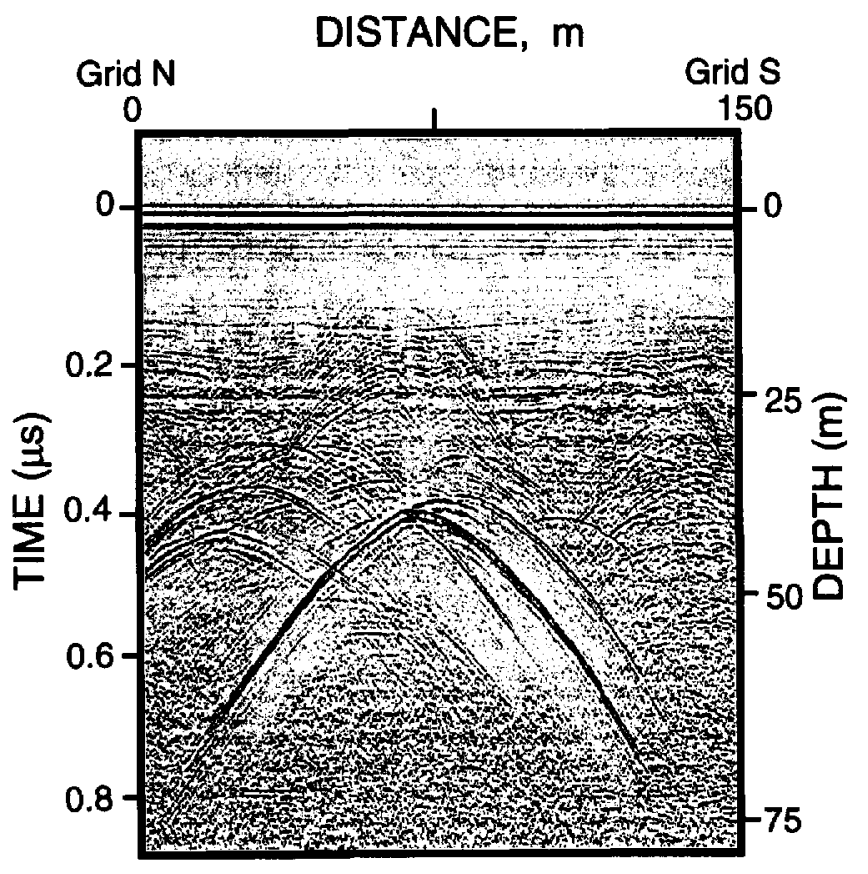

Fig. 7. Radargram from a very smooth-walled freshly opened crevasse. Hyperbolae near the surface can be seen only very faintly. This crevasse is about $0.7 \mathrm{~m}$ wide at the surface, aboul $37 \mathrm{~m}$ deep and covered by a $0.3 \mathrm{~m}$ thick snow bridge.

surface or wall signature. We associate the strong diffractions with the bottoms of the crevasses because in several cases the diffractor depths agreed with the measured depth of the corresponding crevasses. We attribute the lack of a signature from the top edges of these crevasses to their proximity to the surfacc and the antenna-bcam angle, and the weak returns from the walls to a combination of the beam angle, the absence of snow bridges and the smoothness of the crevassc walls.

A third type of return was characterized by relatively weak hyperbolae originating from discontinuities associated with apparent faults (Fig. 8). The layering of the firn associated with these hyperbolae shows offsets of about $1 \mathrm{~m}$, and these hyperbolae are only observed in areas of broad, gentle folding where there are few or no crevasses.

The fourth and most common type of hyperbola. however, we interpret as originating from buricd snow bridges, bccause they are associated with distinct sags or synclines in the strata often bounded on each side by horizontal layers for $100 \mathrm{~m}$ or more (Fig. 9). These hypcrbolae occur in stacks that begin at the depth where the curvature of the syncline first exceeds the curvature of the wave front. Notc that these hyperbolae provide a minimum depth to the original crevasse, since the first hyperbola in a stack is not necessarily correlated with the top of the crevasse.

\section{Orientation and distribution of buried features}

Regardless of the nature of the sources for the hypcrbolac, crossing angles can be determined on the assumption of linearity. The shapes of the hyperbolae are more sensitive to change in the crossing angle at shallow angles than at near-normal angles (Fig. 4). Shallow angles thus provide 

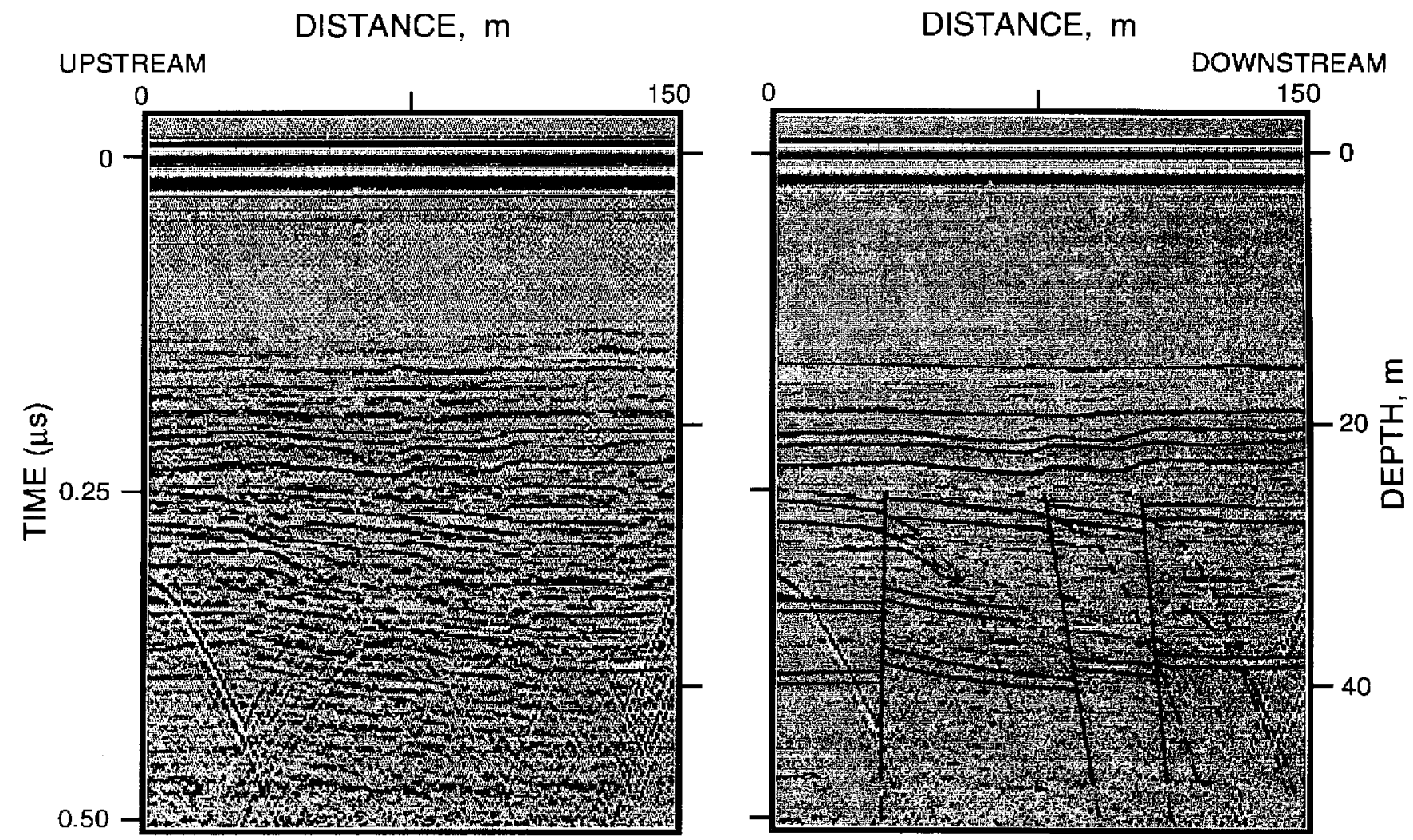

Fig. 8. Radargram showing weak hyperbolae originating from possible faults. The figure on the right is an interpreted section where hvperbolae associated with faults are dashed lines. Offsets are about $1 \mathrm{~m}$. The hyperbolae centered around $60 \mathrm{~m}$ across and $0.35 \mu \mathrm{s}$ depth probably have an off-nadir origin. The vertical disturbance that originates at $60 \mathrm{~m}$ along the sufface is caused by a metallic grid pole.

the most accurate orientations, and are encountered primarily on transverse transects those oriented perpendicular to the flow). Longitudinal transects coriented

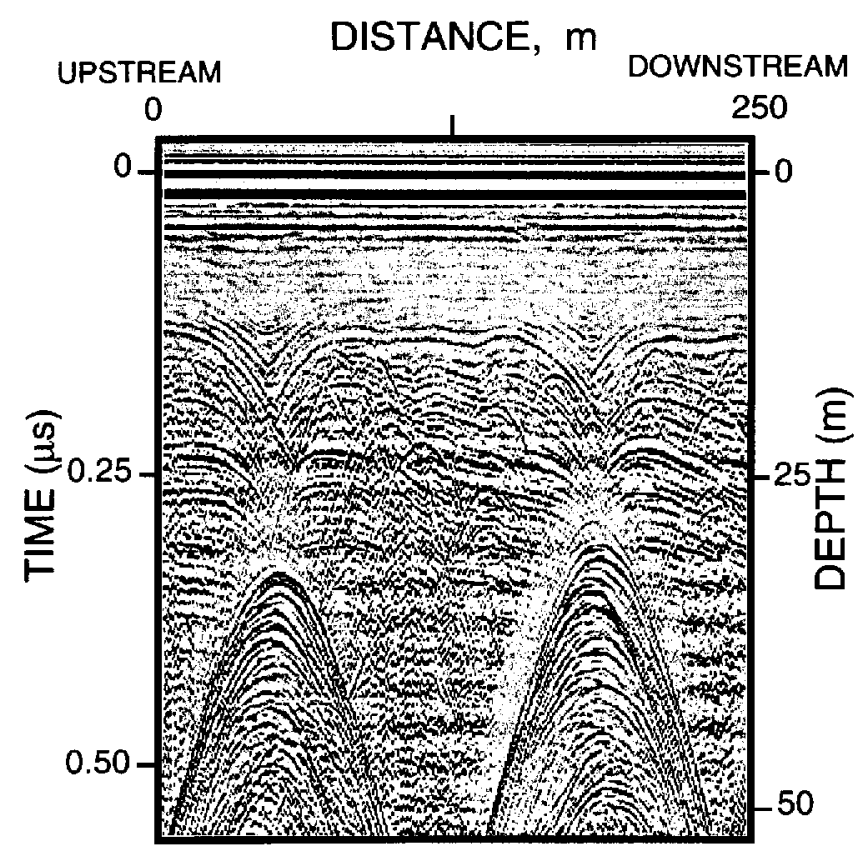

Fig. 9. Radargram showing hyperbolat associated with sagging bridges over buried crevasses. Nole how the relurns from sagging beds change downward into intersecting kiperbolae. parallel to flow) generally provided larger numbers of crossings and thus provide a better estimate of crevasse density. Transverse and longitudinal transects were intcrpreted separately; the results agree to $10^{\circ}$ or better. The ambiguity in the sign of the crossing angles was removed by using correlations between closely spaced or crossing grid lines where they existed, and then by assuming that the orientations vary smoothly between those locations.

It is clear from a histogram of the distribution of hyperbolae with depth (Fig. 10) that there are two distinct crcvassc populations. 'The shallow, young crevasses are currently active and are found in the grid northeastern part of the survey area (Fig. 11a). The orientations of the crcvasses along the upstream northern edge of the grid are in good agreement with those mapped prcviously by Whillans and others (1993). The crevasses downstream of that areat tended to be buricd slightly (hence the tail on the upper population), and therefore were not mapped by the photogrammetric technique employed by Whillans and others. The other crevasses, centered at a depth of about $30 \mathrm{~m}$, have orientations that appear to vary rapidly or abruptly in the central part of the survey area (Fig. $11 \mathrm{~b}$ ). In reality, the two sets of crcvasscs probably intersect in this area. Figure $11 \mathrm{~b}$ shows crevasses on either side of this area crossing the traverselines at approximately equal but opposite angles; since our method of determining orientation cannot distinguish positive from negative angles from a single traverse line, the two sets could easily be mixed. 


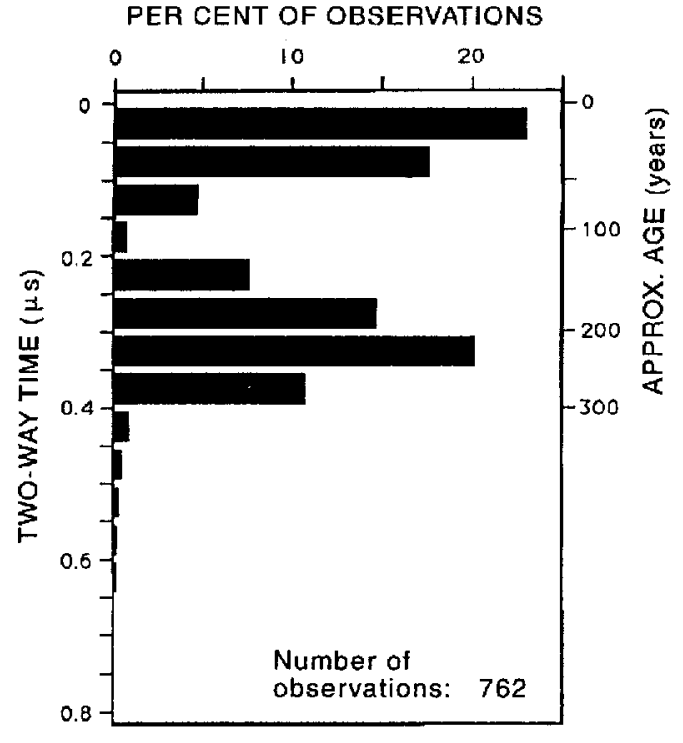

Fig. 10. Histogram of the number of diffractors versus depth. Only the shallowest hyperbola of a stack was counted.

\section{DISCUSSION AND CONCLUSIONS}

The approximatc age of burial for the deeper crevassc population can be calculated using present-day accumulation rates, and assuming that the crevasses reached the surface when they formed (Whillans and others, 1993). (This is a reasonable assumption given that the sags associated with them arc $20-30 \mathrm{~m}$ wide (Fig. 9).) The accumulation rate in the survey area is $86 \mathrm{~mm}$ ice a ${ }^{1}$ (Alley and Bentley, 1988). It increases slowly upstream, averaging about $100 \mathrm{~mm} \mathrm{a}^{-1}$ over the first $200 \mathrm{~km}$ (Whillans and Bindschadler, 1988). Taking $100 \pm$ $10 \mathrm{mma}^{1}$ as the accumulation rate and post-depositional stretching as negligible) leads to an age at the depth of the peak in the deeper crevasse population of $210 \pm 25$ years (Fig. 10). Assuming a linear increase in ice specd from $100 \mathrm{~m}$ a ${ }^{2}$ where crevasses are first observed to form, about $100 \mathrm{~km}$ upstream, to $440 \mathrm{ma}^{-1}$ at the location of the grid (Whillans and Van der Veen, 1993), we calculate the site of initial burial to be about $63 \mathrm{~km}$ upstream. This is in the lower reaches of the rather complex onset region. The likely interpretation is that the crevasses formed as the ice passed through this region. It also indicates that the ice stream has been exhibiting streaming behavior for at least the past 210 years, which is of interest given the apparent ephemeral nature of these ice streams (e.g, the recent stagnation of Ice Stream C about 130 years ago (Retzlaff and Bentley, 1993)).

We cannot reconstruct the state of stress that produced the buricd crevasses because their subsequent strain history is not known. It is interesting, however, that a splayed crevasse pattern, as observed in the area grid west of line 35 (Fig. $1 \mathrm{lb}$ ), is the type expected in an area of transverse tension plus left-lateral shear, without longitudinal extension (Nye, 1952; Vornberger and Whillans, 1990). If this pattern is relatively unaltered from its pre-burial configuration (a fair assumption given the near-center stream location of the crevasses, and the measurements of modern strain rate by Whillans and others (1993)), it

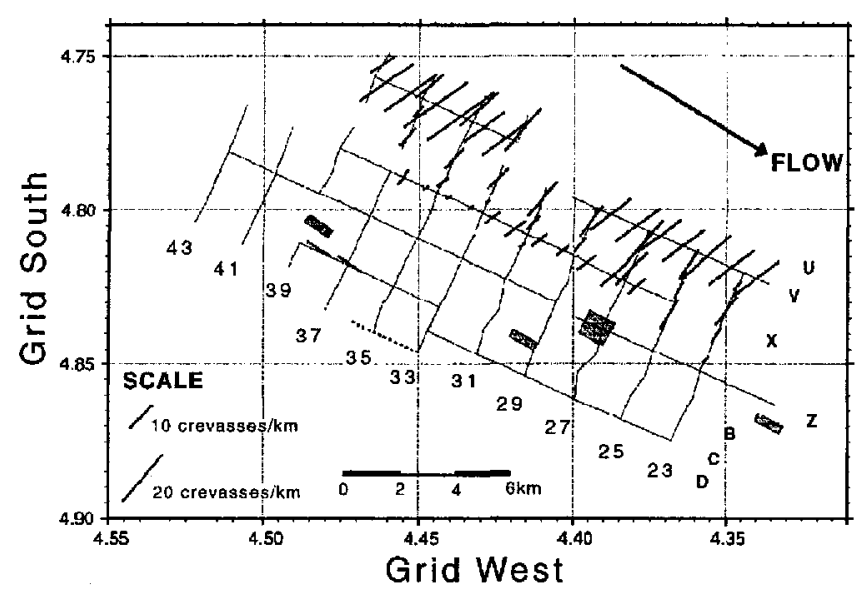

$\mathbf{a}$

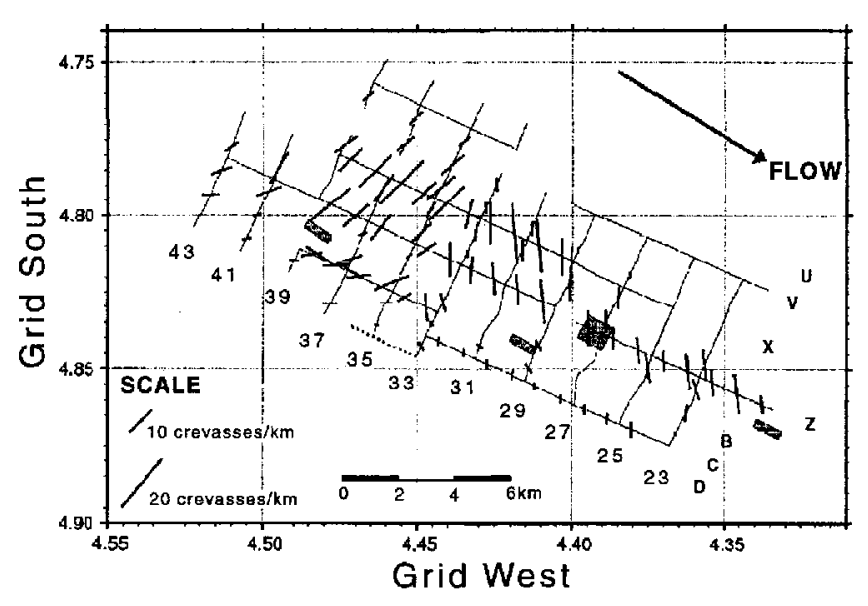

b

Fig. 11. Locations and orientations of the crevasses superimposed on a map of lines surveyed. Crevasse density and orientation are indicated by the length and orientation, respectively, of the heavy-line segments. Continuous lines are survey lines. Letters and numbers identify the lines of the strain grid. The survey-line segment with no crevasses or folds (D33-D36) is dashed. Gray-shaded boxes are areas where crevasse orientation was determined by correlation belween closely spaced grid lines. (a.) The shallower set of crevasses ( $f$. Fig. 10). (b.) The deeper set (cf. Fig. 10). Deeper crevasses are present along the grid northeastern lines but they are obscured by the large number of younger crevasses in that area.

implies that longitudinal tension was not a factor in incorporating this particular icc into the icc stream.

We have no explanation for the crevasses to the grid east of line 35 nor for the $30^{\circ}$ to $60^{\circ}$ change in orientation over a distance of about $2 \mathrm{~km}$. Measured strain rates in the area are small (Whillans, in press; Whillans and others, 1993; Hulbe and Whillans, 1994) and show that rotation cannot account for the observed change over the timc it takes the crevasses to travel $2 \mathrm{~km}$, so the two sets of crevasses (grid east and west of line 35 ) cither have markedly different post-burial strain histories, or more likely, formed in different stress regimes, even though their burial ages are approximately equal. 
In onc area along the grid southeastern edge of the survey, the radar returns showed virtually no visible stratigraphic disturbance (cither crevassing or folding) down to $85 \mathrm{~m}$, the maximum depth of our measurements (Fig. 11). Using the same assumptions as above for accumulation and velocity, the ice at $85 \mathrm{~m}$ is approximately $750 \pm 80$ years old, whereas travel time from the upper reaches of the ice strcam to the location of the grid is only about 440 years. Apparently, this ice, and the ice adjacent to it to the grid south (toward the center of the stream), was incorporated into the ice stream without undergoing sufficient longitudinal strain (or side shear) to cause crevassing or folding, again implying that longitudinal tension was not a factor in incorporating this ice into the ice stream. "Thus suggests that it might be a "raft" (Whillans and others, 1987, 1993), i.e. that it passed into the ice stream probably through the upstream onset zone (since it is near the center of the stream) as a single block.

\section{ACKNOWLEDGEMENTS}

We wish to thank C. Liu and A. N. Novick for their assistance in the field and, in particular, N. Lord, without whom the project could not have been completed. We are grateful to I. M. Whillans and C. Hulbe at The Ohio State University for making the locations of the strain grid poles available to us. We also thank I. M. Whillans and two anonymous revicwers for helpful comments on the manuscript and R. W. Jacobel for discussions at VISAG. This work was supported by grant number DPP90-18530 from the L.S. National Science Foundation. This is contribution Number 541 of the University of Wisconsin-Madison, Geophysical and Polar Rescarch Center.

\section{REFERENCES}

Alley, R. B. and C. R. Bentley. 1988. Ice-core analysis on the Siple Coast of West Antarctica. Ann. Glaciol, 11, $1-7$.

Alley, R. B. and I. M. Whillans. 1991. Changes in the West Antarctic ice sheet. Srience, $254(5034)$. 959-963.

Bogorodskiy, V.V., C.R. Bentley and P.E. Gudmandsen. 1985. Radioglaciology. Dordrecht, Reidel.

Engelhardt, H., X. Hymphrey, B. Kamb and M. Fahnestock. 1990. Physical conditions at the base of a fast moving Antarctic ice stream. Science, 248(4951), $57-59$.

Hulbe, C. L. and I. M. Whillans. 1994. Hualuation of strain rates on Ice Stream B, Antarctica, obtained using differential GPS. Ann. Glacol. 20 see paper in this volume).

Jezek, K. C., C.R. Bentley and J. W. Clough. 1979. Elcctromagnetic sounding of bottom crevasses on the Ross lee Shelf, Antarctica. 7 . Glaciol., 24 90 , 321-330.

Nyc, J. F. 1952. The mechanics of glacier flow. F. Glaciol., 2(12), 82-93.

Retzlaff, R. and C. R. Bentley. 1993. Timing of stagnation of Ice Stream C., West Antaretica, from short-pulse radar studies of buried surface crevasses. 7 . Glaciol, 39 (133), 553-561.

Robin, G. de Q., S. Evans and J. T. Bailey. 1969. 1969. Interpretation of radioccho sounding in polar ice shects. Hhil. Trans. Roy. Soc. London, Series $A, \mathbf{2 6 5}(1166), 437-505$.

Shabtaie, S. and C. R. Bentley, 1987. West Antarctic ice streams draining into the Ross Ice Shrlf: configuration and mass balance. 7. Geophys. Res., 92(B2), $1311-1336$.

Vornberger, P. L. and I. M. Whillans. 1990. Crevasse deformation and examples from Icc Stream B, Antarctica. 7. Glaciol., 36(122), 310.

Whillans, I. M. In press. Ice-stream mechanics. Antarctic 7.6 .5 .

Whillans, I. M. and R.A. Bindschadler. 1988. Mass balance of Ice Stream B, West Antarctica, Ann. Glaciol., 11, 187193.

Whillans, I. M. and C.J. van der Vecn. 1993. New and improved detcrminations of velocity of Ice Streams B and C, West Antarctica. 7. Giaciol., 39 133), 483490 ..

Whillans, I. M. , J. Bolzan and S. Shabtaic. 1987. Velocity of Ico Streams B and C, Antarclica. ff. Geophys. Res., 92(B9), 8895-8902.

Whillans, I. M., M. Jackson and Y. -H. Yseng. 1993. Velocity pattern in a transect across Ice Stream B, Antarctica. J. Glaciol., 39(133). $562-572$.

The accuracy of references in the text and in this list is the responsibility of the authors, to whom queries should be addressed. 